Review

http://dx.doi.org/10.17784/mtprehabjournal.2014.12.164

\title{
Methods of evaluating postural deviations of the spine used in national studies: a systematic
} review.

\author{
Métodos de avaliação de desvios posturais da coluna vertebral utilizados em estudos nacionais: \\ uma revisão sistemática.
}

José Nunes da Silva Filho ${ }^{(1)}$. Post-Graduate Strictu Sensu Program de in Ciências do Exercício e do Esporte, Universidade Gama Filho (UGF), Rio de Janeiro (RJ), Brazil.

\begin{abstract}
Introduction: The spine related diseases have been increasing sharply and causing serious problems for public health. Having a postural assessment with one of the important factors in the prevention and/or treatment of these problems. Objectives: To determine which methods of spinal postural assessment has been used in studies and national journals published recently. Methods: This study is a systematic review, which followed the recommendations (PRISMA) "Transparent report of Systematic Reviews and Meta-analysis." The search data Began with the choice of key terms and synonyms following the Health Sciences Descriptors DeSC and MeSH (Medical Subject Headings). Due to achieve the main objective of the research, we selected only studies of national authors and journals published between the year 2013 to Feb/2014, yet fitting, made any kind of spinal postural assessment. Conducted a descriptive statistical checking the frequency percentages by software (IBM $®$ SPSS $®$ Statistic, vs 21, New York/USA 2012. Results: 25 studies were included, and the methods of evaluation were: photogrammetry $(36.7 \%, \mathrm{n}=11)$; Posturógrafo $(16.7 \%, n=5)$; X-Ray $(10 \%, n=3)$; Postural Visual Evalution $(23.3 \%, n=7)$ Goniometry $(3.3 \%, n=1)$. Conclusions: it is concluded between national studies photogrammetry is the postural assessment methods most used today.

Keywords: Posture; Spinal Diseases; Measurement Equipment.

\section{Resumo}

Introdução: As doenças relacionadas à coluna vertebral vêm crescendo abruptamente e gerando sérios problemas para saúde pública. Tendo a avaliação postural com um dos fatores importante na prevenção e/ou tratamento desses problemas. Objetivos: verificar quais métodos de avaliação postural da coluna vertebral vem sendo usados nos estudos e periódicos nacionais publicados recentemente. Métodos: Este é estudo de revisão sistemática, que seguiu as recomendações (PRISMA) "Transparent report of Systematic Reviews and Meta-análise". A busca de dados inciou-se com a escolha dos termos chaves e sinônimos seguindo os Descritores em Ciências da Saúde (DESC), e MeSH (Medical Subject Headings). Em virtude de atingir o objetivo principal da pesquisa, selecionaram-se apenas estudos de autores e periódicos nacionais publicados entre o ano de 2013 a Fev/2014, cabendo ainda, realizado qualquer tipo de avaliação postural da coluna vertebral. Realizou uma estatística descritiva verificando a frequência em porcentagens através do software (IBM $\AA$ SPSS ${ }^{\circledR}$ Statistic, vs 21, Nova York/EUA, 2012. Resultados: Foram contemplados 25 estudos, e os métodos de avaliação encontrados foram: fotogrametria (36,7\%, $n=11)$; Avaliação Postural Visual $(23,3 \%, n=7)$; Posturógrafo $(16,7 \%, n=5)$; Raio-X $(10 \%, n=3)$; Goniometria $(3,3 \%, n=1)$. Conclusão: Conclui-se entre os estudos nacionais a fotogrametria é o métodos de avaliação postural mais utilizado atualmente.
\end{abstract}

Palavras-Chave: Postura; Doenças da Coluna Vertebral; Equipamentos de Medição.

Received: 29 November 2013. Accepted: 13 March 2014. Published: 30 March 2014.

1. Scholarship from Conselho Nacional de Desenvolvimento Científico e Tecnológico [CNPq]; Student of Post Graduate Program (Stricto Sensu) in Ciências do Exercício e do Esporte from Universidade Gama Filho (UGF), Rio de Janeiro (RJ), Brazil. 


\section{INTRODUCTION}

Currently those diseases related to spinal have been growing sharply causing serious problems for public health. Those which are responsible for much of absent from work, because, according to the Instituto Nacional do Seguro Social (INSS) in 2003 the problems related to spinal region, in particular pain in this region caused a total of 20,341 of the 387,950 work accidents. ${ }^{(1)}$

The spine problems when not congenital, may be from genetic, biological or even psychological.(2) And yet, it is believed that many other factors may cause postural deviations, and over time to provide serious the spinal problems. And among the factors that may cause postural deviations, we highlight the labor activities maintained for long periods in equal positions or movements; ${ }^{(3)}$ obesity status, ${ }^{(4)}$ large abdominal girth, ${ }^{(5)}$ wrong practice and/or bad oriented physical activity, ${ }^{(6)}$ or sports. ${ }^{(7)}$ Generating an imbalance in the musculoskeletal structures, causing postural deviations and different problems of spine. ${ }^{(8-10)}$

Postural problems can occur both in children ${ }^{(11,12)}$ and adults and the elderly, ${ }^{(13,14)}$ however, it is believed that the greater the age, the greater the likelihood of having postural deviations, ${ }^{(5)}$ which can be justified second Aikawa, Braccialli, Padula(15) proper body posture is closely correlated with concepts of strength, balance, flexibility and neuromuscular coordination, along with all its mechanisms.

Postural deviations occur in various segments of the body, however, is believed to be the trunk, the body part most influential for maintaining body posture, being the axial skeleton of the human body, ${ }^{(16)}$ and any changes that may significantly interfere with the body posture of the individual, thus causing limitations in personal activities, interfering negatively in habits and quality of life. ${ }^{(17-19)}$

Because there is a considerable increase in the prevalence of postural deviations, and problems arising from these it was sought to establish reliable methods of postural assessment, however, several methods have been used and improved over the years. ${ }^{(9)}$ Thus, it is justified to determine which methods of postural assessment are currently being used, and detailed investigations on the spine while maintaining body posture can contribute understanding and measurement of postural control body misalignments, efficacy of therapeutic interventions, and consequently assist in the prevention and treatment of problems caused by poor posture. $(9,20)$

However, the aim of this study was to determine which methods of postural assessment of the spine have been used in studies and national journals published recently.

\section{MATERIAL E METHODS}

This systematic review study, ${ }^{(21)}$ which followed the
(PRISMA) recommendations "Transparent report of Systematic Reviews and Meta-analysis" (22) Being held in national databases and international databases: SciELO, PubMed and the search site Google Scholar (G.S) for having a large number of journals that are not available in the above bases. The selection and choice of studies were done by a Physical Education professional.

\section{Search for articles}

There was a previous selection of terms and keywords, following the Descritores em Ciências da Saúde (DECS) $^{(23)}$ and of MeSH (Medical Subject Headings) dictionary for indexing articles in PubMed. After such a search, the terms were selected in Portuguese: Postura, Coluna, Doenças da Coluna Vertebral; Equipamentos de Medição, and English: Posture, Spinal, Spinal Diseases; Measurement Equipment. The terms were entered in the search sites, separated by Boolean operators "AND" and "OR". Still trying to capture all studies, also conducted a simple search with the terms "Postural Assessment AND Spine". The search and selection of articles referred to took place between Jan/2014 and Feb/2014.

\section{Articles inclusion criteria}

In view to achieve the research objective, we selected only studies of Brazilian authors who have published in national journals between the years 2013 to Feb/2014, yet fitting, made any kind of postural evaluation of the spine in humans. Any studies of completion were awarded: Monographs, dissertations and/ or theses.

\section{Eligibility Criteria}

Studies that have gone through the initial filter, found some term in reading the title of the study were selected using the technique suggested by Lakatos, Marconi, (24) by reading the summary, and the case would meet the criteria, was realized thorough reading of Article ultimately choosing between inclusion or exclusion of the article. After all established criteria were considered for the survey 25 studies. Represented in Figure 1, through the organization schema and inclusion of studies in the search following.

\section{Statistical Analysis}

After done all collecting data, began a statistical analysis using software (IBM $®$ SPSS $®$ Statistic, vs 21 , New York / USA 2012), checking through descriptive statistics only simple frequency shown in percentage in the methods postural assessment.

\section{RESULTS}

Were found 25 studies published in 2013, and among them, 06 different methods to assess postural deviations of the spine, still found in some of the meth- 
ods found, 06 different software, these who assisted assessment, contributing to the method can be quantitative variables.

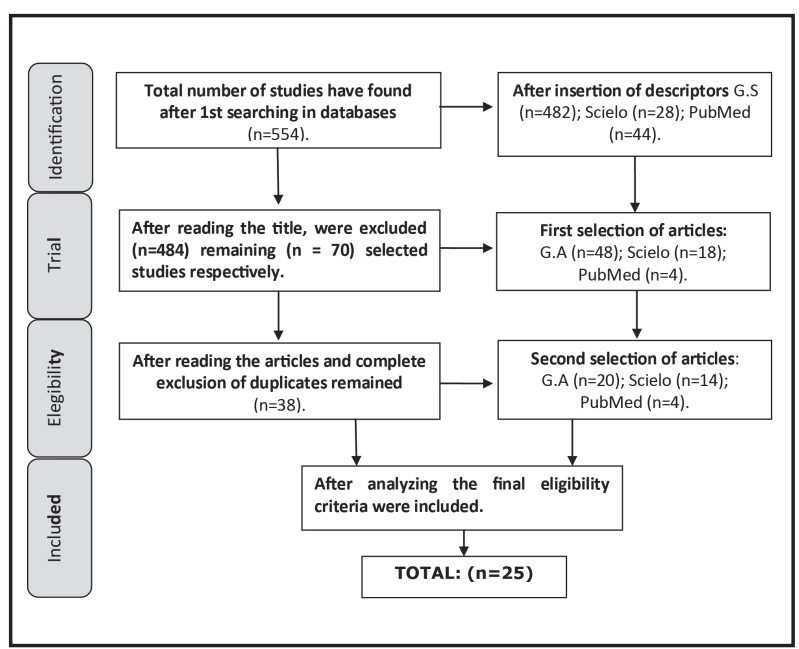

Figure 1. Flowchart of the studies included in the survey according to the eligibility criteria.
In Figure 2, it can be seen that among the six methods of postural assessment in the studies, which was more present was photogrammetry, this amounted to a percentage of $(36.7 \%, \mathrm{n}=11)$ of the studies included.

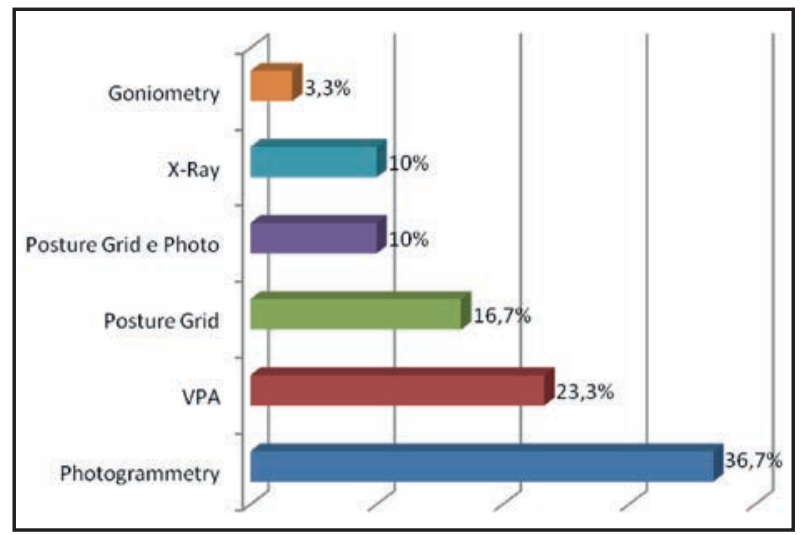

Figure 2. Percentage of the methods used in reviews. Subtitle: VPA: Visual Postural Assessment.

Table 1. Displays the description of the contemplated studies.

\begin{tabular}{|c|c|c|c|c|}
\hline Study & Year & $\mathbf{N}^{\circ}$. & Methods & Soft \\
\hline Barbosa et al. ${ }^{(35)}$ & 2013 & 85 & Photogrammetry & Corel Draw $®$ \\
\hline Borges; Fernandes; Bertongello.(2) & 2013 & 18 & Photogrammetry & Sapo® \\
\hline Bueno; Rech. ${ }^{(13)}$ & 2013 & 864 & VPA & - \\
\hline Colpo; Daronco; Balsan.(36) & 2013 & 23 & VPA & - \\
\hline Comerlato; Scanegatta; Rosset.(30) & 2013 & 01 & Posturography \& Photo & - \\
\hline Cunha et al.(37) & 2013 & 31 & Photogrammetry & Sapo® \\
\hline Dos Santos Pinto et al.(28) & 2013 & 70 & Posturography & - \\
\hline Feijó et al. ${ }^{(38)}$ & 2013 & 18 & Photogrammetry & APDIO \\
\hline Ferreira; Barela; Barela. ${ }^{(16)}$ & 2013 & 20 & Photogrammetry & APAS \\
\hline Galo et al. ${ }^{(9)}$ & 2013 & 19 & Photogrammetry & Posturograma $®$ \\
\hline Gimenes et al. ${ }^{(39)}$ & 2013 & 15 & Photogrammetry & Sapo ${ }^{\circledR}$ \\
\hline Kulsheski et al.(4) & 2013 & 30 & X-Ray & - \\
\hline Lima et al. ${ }^{(40)}$ & 2013 & 16 & VPA & - \\
\hline Macedo et al. ${ }^{(41)}$ & 2013 & 09 & Photogrammetry & Corel Draw $®$ \\
\hline Magalhãoes; Trippo; Lima Júnior. ${ }^{(42)}$ & 2013 & 19 & Photogrammetry & Sapo® \\
\hline Meireles et al.(43) & 2013 & 60 & Photogrammetry & - \\
\hline Oliveira; Horodéski(27) & 2013 & 01 & Goniometry & - \\
\hline Pereira et al. ${ }^{(44)}$ & 2013 & 262 & VPA & - \\
\hline Sedrez et al.(45) & 2013 & 20 & Posturography \& Photo & - \\
\hline Silva et al. ${ }^{(46)}$ & 2013 & 14 & VPA & - \\
\hline Sinzato et al. ${ }^{(29)}$ & 2013 & 33 & Photogrammetry & Sapo® \\
\hline Souza et al.(11) & 2013 & 476 & Posturography \& X-Ray & - \\
\hline Steidl et al. (47) & 2013 & 13 & VPA & - \\
\hline Tamura; Gouvêa; Bertolini. ${ }^{(48)}$ & 2013 & 297 & VPA \& X-Ray & - \\
\hline Valduga et al.(14) & 2013 & 70 & Photogrammetry & Sapo® \\
\hline
\end{tabular}

Subtitle: VPA: Visual Postural Assessment; APDIO: Postural assessment from digital image; APAS: Performance Analys System; ${ }^{\circ}$ : Number of subjetcs. 


\section{DISCUSSION}

Can be seen in the present study that the method of computed radiography (X-ray), although in a few studies $(10 \%, n=3)$, is still being used in academic studies. The $x$-ray is considered the most reliable methods "gold standard" for evaluation of deviations in the spine ${ }^{(25)}$ by offering a vision of all his vertebrae and curves. However, the method also presents serious risks to the health of people exposed to this type of assessment, being an invasive method that exposes patients to damage to the body(26) since there are reports of cases that resulted in death. And the assessment carried out with X-ray pose risks to health, which studies have sought over the years establish a reliable methods, presenting no risk to health assessed, being practical and inexpensive.

And among the methods currently found in studies conducted in addition to the x-ray were found methods of visual postural assessment (VPA), ${ }^{(13)}$ goniometer, ${ }^{(27)}$ posturography ${ }^{(28)}$ and photogrammetry, ${ }^{(29)}$ or even some combination of these methods in the same assessment. $(11,30)$ When discussing these methods, it is noticed that some are present predominantly subjective characteristics, being composed of qualitative analyzes, as in the case of VPA, and posturography. ${ }^{(8)}$ However, with advancement in technology, have been developing methods that enable better measurement of the spine, faster and more reliably, transforming reviews before predominantly qualitative approach to quantitative assessments.

These changes aimed at more quantitative analysis, was also found in the present study because it was realized that although VPA and posturography are being used in the current study $(23.3 \%, \mathrm{n}=7)$ and $(16.7 \%$, $\mathrm{n}=5)$, respectively, the method was found more photogrammetry, which was present in $(36.7 \%, n=11)$ of the studies.

This research confirmed that photogrammetry has been a widely used technique ${ }^{(31)}$ and likely to increase, given that the insertion of images and postural assessment software is allowing postural assessments, estimate more precisely the postural deviations, ${ }^{(32)}$ for a faster way, and the more subjective assessments, the period in which the reviewer takes to assess the measures of all angles of the body assessed on the person generates a lengthy process that can certainly affect the reliability of the measurements. ${ }^{(20)}$ Photogrammetry has also proved superior to VPA when the Iunes(33) study showed greater concordance between the results. Moreover, since its validity and reliability had previously studied ${ }^{(32,34)}$ and shown to be valid and reliable to measure linear and angular asymmetry in body posture by enabling measure angles and/or horizontal and vertical distances between the body segments. ${ }^{(31)}$

\section{CONCLUSION}

It is concluded that the methods of postural assessment of the spine between the most used journal articles and national authors today are: photogrammetry, visual assessment, and posturógrafo. Photogrammetry being the most used method.

\section{ACKNOWLEDGEMENTS}

We appreciate the support and funding agencies Conselho Nacional de Desenvolvimento Científico e Tecnológico (CNPq) and Corpo \& Vida Equipamentos Esportivos LTDA-ME (PVH-RO).

\section{REFERENCES}

1. Barbosa FSS, Gonçalves M. A proposta biomecânica para a avaliação de sobrecarga na coluna lombar: efeito de diferentes variáveis demográficas na fadiga muscular. Acta ortop bras. 2007;15(3):132-7.

2. Borges CdS, Fernandes LFRM, Bertoncello D. Correlação entre alterações lombares e modificações no arco plantar em mulheres com dor lombar. Acta ortop bras. 2013;21(3):135-8.

3. Moura Neto ABd, Silva MCd. Diagnóstico das condições de trabalho, saúde e indicadores do estilo de vida de trabalhadores do transporte coletivo da cidade de Pelotas-RS. Revista Brasileira de Atividade Física \& Saúde. 2013;17(5):347-58.

4. Kulcheski AL, Soler X, Graells MLB, Baretta G. Avaliação angular do equilíbrio sagital em pacientes obesos. Coluna/Columna. 2013;12(3):224-7.

5. Porto F, Gurgel JL, Russomano T, Farinatti PdTV. Shadow Moire technique to measure deformity of the trunk surface in the elderly: a population-based study In: Bessette A, Rousseau, Coralie $M_{, \prime}$, editors. Scoliosis: Causes, Symptoms and Treatment. New York: Nova Biomedical; 2012. p. 73-90.

6. Falqueto FA, Helrigle C, Malysz T. Prevalência de alterações posturais em praticantes regulares de musculação. Ter Man. 2011;41(9):51-6.

7. Kleinpaul JF, Mann L, Santos SGd. Lesões e desvios posturais na prática de futebol em jogadores jovens Injuries and postural deviations in young players' soccer practice. Fisioter pesqui. 2010;17(3):236-41.

8. Kendall F, McCreary E, Provance P. Músculos: provas e funções - com postura e dor. 4 ed. São Paulo: Manole; 1995 
9. Galo ÍDC, Namba DM, Soares JR, Malysz T. Análise comparativa das alterações posturais de praticantes regulares de Taekwondo e de indivíduos sedentários. ASSOCIATION POSTUROLOGIE INTERNATIONALE. 2013;11(53):319.

10. Penha PJ, João SMA, Casarotto RA, Amino CJ, Penteado DC. Postural assessment of girls between 7 and 10 years of age. Clinics. 2005;60(1):9-16.

11. Souza FId, Ferreira RBD, Labres D, Elias R, Sousa APMd, Pereira RE. Epidemiology of adolescent idiopathic scoliosis in students of the public schools in Goiânia-Go. Acta ortopedica brasileira. 2013;21(4):223-5.

12. Graup S, Santos S, Moro ARP. Estudo descritivo de alterações posturais sagitais da coluna lombar em escolares da Rede Federal de Ensino de Florianópolis. Rev Bras Ortop. 2010;45(5):453-9.

13. Bueno RdCdS, Rech RR. Desvios posturais em escolares de uma cidade do Sul do Brasil. Revista paulista de pediatria : orgao oficial da Sociedade de Pediatria de Sao Paulo. 2013;31(2):237-42.

14. Valduga R, Valduga LVA, Almeida JAd, Carvalho GA. Relação entre o padrão postural eo nível de atividade física em idosas. Revista Brasileira de Ciência e Movimento. 2013;21(3):5-12.

15. Aikawa AC, Braccialli LMP, Padula RS. Efeitos das alterações posturais e de equilíbrio estático nas quedas de idosos institucionalizados. Revista de Ciências Médicas. 2012;15(3).

16. Ferreira DMA, Barela AMF, Barela JÂ. Influência de calços na orientação postural de indivíduos com escoliose idiopática; Influence of the shoe lift in the postural orientation in individuals with idiopathic scoliosis. Fisioter mov. 2013;26(2):337-48.

17. Aebi M. The adult scoliosis. European spine journal : official publication of the European Spine Society, the European Spinal Deformity Society, and the European Section of the Cervical Spine Research Society. 2005;14:92548.

18. Takahashi T, Ishida K, Hirose D, Nagano Y, Okumiya K, Nishinaga M, et al. Trunk deformity is associated with a reduction in outdoor activities of daily living and life satisfaction in community-dwelling older people. Osteoporos Int. 2005 16:273-9.

19. Dolphens M, Cagnie B, Coorevits P, Vanderstraeten G, Cardon G, D'Hooge R, et al. Sagittal standing posture and its association with spinal pain: a school-based epidemiological study of 1196 Flemish adolescents before age at peak height velocity. Spine. 2011;37(19):1657-66.

20. Fortin C, Ehrmann Feldman D, Cheriet F, Labelle H. Clinical methods for quantifying body segment posture: a literature review. Disability and Rehabilitation. 2011;33(5):367-83.

21. Thomas JR, Nelson JK, Silverman SJ. Métodos de Pesquisa em Atividade Física. Porto Alegre: Artmed; 2012.

22. Moher D, Liberati A, Tetzlaff J, Altman DG. Preferred reporting items for systematic reviews and meta-analyses: the PRISMA statement. Annals of internal medicine. 2009;151(4):264-9.

23. Pereira TA, Montero EFdS. DeCS terminology and the new rules on orthography of Portuguese language: guidelines for an update. Acta Cirurgica Brasileira. 2012;27(7):509-14.

24. Lakatos E, Marconi M. Fundamentos de pesquisa metodológica científica. Revisada e ampliada. São Paulo: Atlas; 2003.

25. Malfair D, Flemming AK, Dvorak MF, Munk PL, Vertinsky AT, Heran MK, et al. Radiographic evaluation of scoliosis: review. American Journal of Roentgenology. 2010;194(3_supplement):S8-S22.

26. Caruncho MV. Os efeitos da radiação diagnóstica. Revista Brasileira de Medicina de Família e Comunidade. $2011 ; 6(19): 116-7$.

27. Oliveira LJ, Horodéski JS. Efeito do método Pilates na redução do grau de escoliose em paciente com Osteocondrose-Estudo de Caso. Saúde e meio ambiente: revista interdisciplinar. 2013;2(1):44-58.

28. Dos Santos Pinto RF, Freitas J, Félix L, de Oliveira S. A relação entre o mobiliário escolar não regulável e os distúrbios posturais em alunos universitários. Ciência Atual-Revista Científica Multidisciplinar das Faculdades São José. $2013 ; 1(2)$.

29. Sinzato CR, Taciro C, Pio CdA, Toledo AMd, Cardoso JR, Carregaro RL. Effects of 20 sessions of Pilates method on postural alignment and flexibility of young women: pilot study. Fisioterapia e Pesquisa. 2013;20(2):143-50.

30. Comerlato T, Scanegatta S, Rosset D. Efeitos do método de Reeducação Postural Global (RPG) no tratamento da cifose de scheuermann. Revista FisiSenectus. 2013;1:10-9.

31. Sacco I, Alibert S, Queiroz B, Pripas D, Kieling I, Kimura A, et al. Confiabilidade da fotogrametria em relação a goniometria para avaliação postural de membros inferiores. Rev Bras Fisioter. 2007;11(5):411-7.

32. Iunes D, Castro F, Salgado H, Moura I, Oliveira A, Bevilaqua-Grossi D. Confiabilidade intra e interexaminadores e repetibilidade da avaliação postural pela fotogrametria. Rev Bras Fisioter. 2005;9(3):327-34.

33. Iunes D, Bevilaqua-Grossi D, Oliveira A. Análise comparativa entre avaliação postural visual e por fotogrametria computadorizada; Comparative analysis between visual and computerized photogrammetry postural assessment. Rev bras fisioter. 2009;13(4):308-15. 
34. Döhnert M, Tomasi E. Validade da fotogrametria computadorizada na detecção de escoliose idiopática adolescente. Rev Bras Fisioter. 2008;12(4):290-7.

35. BarBosa JAN, Amorin MHC, Zandonade E, Delaprane M. Avaliação da postura corporal em mulheres com câncer de mama. Rev Bras Ginecol Obstet. 2013;35(5):215-20.

36. Colpo IMS, Daronco LSE, Balsan LAG. Postural evaluation, pain and fitness of hydrogymnastics practitioners. Revista Dor. 2013;14(1):35-8.

37. Cunha EFD, Patrício NA, Macedo MC, Sena C, Kruschewsky R, Castro BG, et al. Postural profile of patients with HAM/TSP: computerized and baropodometric assessment. Brazilian Journal of Medicine and Human Health. $2013 ; 1(1)$.

38. Feijó GdS, Gontijo KNS, Ribeiro LP, Mazetto L, Noll M, Candotti CT. A influência da dança de saláo sobre a postura corporal de alunos de uma escolha de dança em Bento Gonçalves-RS. Cinergis. 2013;14(1).

39. Gimenes RO, Tacani PM, Junior SAG, de Campos CM, Batista PAN. Fisioterapia aquática e de solo em grupo na postura de mulheres mastectomizadas. J Health Sci Inst.31(1):79-89.

40. Lima LRO, Cortez ACL, Silva GCB. Perfil postural em escolares do $6^{\circ}$ ao $9^{\circ}$ ano, praticantes e não praticantes de ballet clássico de uma escola da rede particular da cidade de Timon-MA. Northeast Brazilian Health Journal (Revista Piauiense de Saúde). 2013;2(1):4.

41. Macedo RMB, Ulbricht L, da Vinha Ricieri D, Preis C, Duarte JM, Neto LB. Análise cinemática 2D da postura ortostática de ciclistas lombálgicos. Revista UNIANDRADE. 2013;14(1):07-23.

42. Magalhães AR, Trippo KV, de Lima Junior AS. PEPIN-Programa de Educação Postural Integrada: motricidade, cognição e emoção como elementos para uma educação postural. Revista Uniabeu. 2013;6(13):1-12.

43. Meireles HR, Azevedo JH, Gonçalves Lopes Junior JE, Jácome de Figueiredo AD. INFLUÊNCIA DAS CARTEIRAS ESCOLARES NA POSTURA DE ALUNOS DA REDE PÚBLICA DE ENSINO. Fisioterapia \& Saúde Funcional. 2013;2(1):3541.

44. Pereira DS, Castro SS, Bertoncello D, Damiao R, Walsh IA. Relationship of musculoskeletal pain with physical and functional variables and with postural changes in school children from 6 to 12 years of age. Brazilian journal of physical therapy. 2013;17(4):392-400.

45. Sedrez JA, de Oliveira DS, Noll M, Fonseca CD, Candotti CT. Reprodutibilidade intra-observador de um protocolo para avaliação postural em escolares. Pensar a Prática. 2013;16(2).

46. Silva AF, Dellinghausen CdM, de Avila FS, Souza LFd, Etchepare Daronco LS, Peixe LA, et al. Desvios posturais, índices de dor e resistência muscular localizada abdominal em bailarinas de Jazz. BIOMOTRIZ-Revista Científica da Universidade de Cruz Alta. 2013;7(1).

47. Steidl EMdS, Friedrich FF, da Pieve Antunes V, Beuter CR. Avaliação da postura corporal e do padrão respiratório em crianças asmáticas. Saúde (Santa Maria). 2013;39(1):131-8.

48. Tamura TMY, Gouvêa JAG, Bertolini SM. Análise da Postura Sentada e Ortostática de Acadêmicos de Fisioterapia. Revista Cesumar-Ciências Humanas e Sociais Aplicadas. 2013;18(2). 